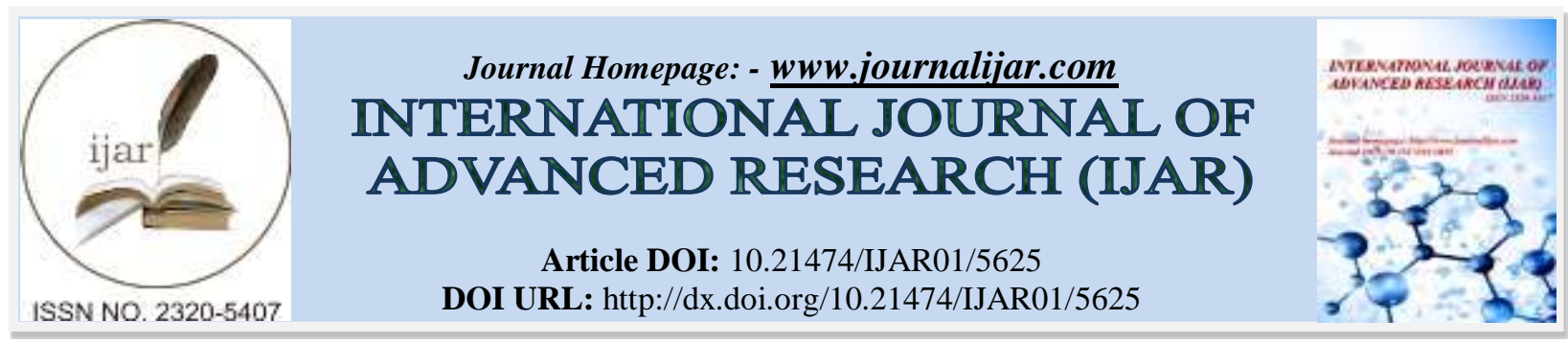

RESEARCH ARTICLE

\title{
OPTIMIZATION OF LIPASE ACTIVITY FROM STAPHYLOCOCCUS GALLINARUM AND ITS PARTIAL PURIFICATION.
}

Amita Madhukar Kocharekar and Meenal Shriniwas Dukhande.

Department of Microbiology, Guru Nanak Khalsa College, Matunga, Mumbai-19, Maharashtra, India.

\section{Manuscript Info}

Manuscript History

Received: 14 August 2017

Final Accepted: 16 September 2017

Published: October 2017

Key words:-

Lipolytic, Lipase, Staphylococcus gallinarum, Spoilt Butter,

\section{Abstract}

Lipolytic enzymes from microbial sources have been explored in budding research in various arenas. A lipase producing bacterium was isolated from spoilt butter and identified as Staphylococcus gallinarum. The present study was carried out to maximize activity of enzyme lipase from Staphylococcus gallinarum. For this, variations in carbon, nitrogen and oil sources of original glucose yeast extract broth supplemented with oil were carried out. High lipase activity was observed with $2 \%$ glucose, $1 \%$ peptone, $1 \%$ olive oil, 0.15 optical density at $\mathrm{pH} 7.0,37{ }^{\circ} \mathrm{C}$ at $200 \mathrm{rpm}$. Partially purified enzyme with $8329.6 \mathrm{U} / \mathrm{mg}$ specific activity, 29.6 fold purification and $19.22 \%$ yield was obtained by fractional ammonium sulphate precipitation method.

Copy Right, IJAR, 2017,. All rights reserved.

\section{Introduction:-}

Lipase belongs to the superfamily of serine hydrolases. They catalyzes synthesis, hydrolysis and transesterification reactions (Ramesh, 2014). They are noteworthy biotechnologically relevant enzymes as an industry prefers green catalysts as compared to chemical one. Lipases find immense application in diary industries (hydrolysis of milk fats, lipolysis of butter, ripening of cheese, etc.), detergent industries (removing oil stains from clothes, tanning leather, etc.), and food and beverages industries (synthesis of flavoring compounds) (Lux, 2007; Ortansa, 2015). In recent decades, lipases are exploited in biodiesel production from waste and left over cooking oils. They are used to modify properties of vegetable oils and fats into value added products. Thus, comparatively cheap and undesirable lipid can be improved into higher value fat. In this regards, palm oil was modified by lipase catalyzed transesterification reaction into cocoa butter equivalent and it is used as substitute for original cocoa which is very costly (Denise et al., 2015). Lipases have potential in cosmetics and perfumeries industries. It shows activity in aroma and surfactant production (Brault, 2014; Croitoru et al., 2011). Today, valuable flavoring compounds and esters are produced by using catalytic ability of lipase. They are able to catalyze synthesis of fruity flavor which otherwise requires extraction procedure from natural sources (Longo, 2006). Modification of milk fats and synthesis of human milk fat substitutes is another attractive research area. Lipases are used in bioremediation of oil spills. The waste of lipid processing industries and restaurants are cleaned by using lipases of different origin. Lipases are used in biosensors as diagnostic tool to detect infectious diseases and to monitor lipid profile of patient (Kocharekar, 2017). Owing to all these, market value of lipase is being upsurge in past spans and newer microbes are screened for production of lipase with appropriate property.

Lipases are produced by plants, animals and micro-organisms; however lipases of microbial origin have great importance due to their substrate specificity, ease for isolation, genetic manipulation and production. Growth conditions such as availability of carbon and nitrogen sources, presence of inducer, inhibitor, incubation 
temperature, $\mathrm{pH}$, amount of inoculum, oxygen, etc. can influence the synthesis of lipase. Lipid carbon sources are reported as essential for obtaining maximum lipase yield. Studies on optimization of medium and parameters for maximizing lipase production have been carried out by many researchers. The organisms are generally grown in complex medium containing lipid, oils and fats as carbon sources, organic and inorganic nitrogen sources, etc. A pH range of 5.0 to 10.0 has been used for lipase production (Veerapagu, 2013). In sight of this, in the present research article, optimization of lipase enzyme from Staphylococcus gallinarum has been discussed. Enzymes are generally produced by submerged fermentation. Glucose yeast extract broth is mainly used to produce lipase of bacterial or fungal origin; still optimization of the medium constituents is important in order to maximize the yield and activity. Thus different components like carbon, nitrogen sources and oils were optimized.

\title{
Material and methods:-
} Culture maintenance:-

Bacterial culture was isolated from spoilt butter sample on Goradkowa's tributyrin agar medium. 16s rRNA sequencing revealed that the isolate is Staphylococcus gallinarum. It was maintained on nutrient agar slant at $4^{\circ} \mathrm{C}$ until used.

\section{Materials:-}

All chemicals used in this research were of analytical grade. In all experiments, the measurements were carried out in triplicate and the data represents mean $\pm \mathrm{SD}$ of values.

\author{
Methods:- \\ Optimization of different parameters for maximizing enzyme lipase activity from Staphylococcus gallinarum:- \\ The culture conditions like optical density, agitation, incubation period, temperature, $\mathrm{pH}$ and carbon, nitrogen and \\ oil sources were optimized for maximizing lipase production using one variable approach. i.e. one parameter was \\ changed keeping the other constant at a time.
}

Optimum inoculum concentration for maximizing lipase activity was studied using different culture densities. For this, 24 hours old culture was centrifuged at $5000 \mathrm{rpm}$. Bacterial cells from the pellet were used and varying concentration of culture was prepared by adjusting the optical density colorimetrically at $520 \mathrm{~nm}$. Optical densities of $0.1,0.15$ and 0.2 were used. $1 \mathrm{ml}$ culture of respective optical density was seeded in original production medium ( $0.5 \%$ glucose, $1 \%$ peptone, $1 \%$ olive oil). Effect of $\mathrm{pH}$ and temperature of fermentation medium for lipase production was studied by varying the $\mathrm{pH}$ from 5.6, 7.0 and 9 while keeping the other parameters unchanged. For selection of optimum temperature for the production, temperatures were varied from $25^{\circ} \mathrm{C}, 35^{\circ} \mathrm{C}$ and $45^{\circ} \mathrm{C}$. Effect of agitation was studied by incubating the enzyme production medium inoculated with culture under static condition at optimum temperature and orbital shaker condition at varying speeds of $100 \mathrm{rpm}, 150 \mathrm{rpm}, 200 \mathrm{rpm}$ and $250 \mathrm{rpm}$. Effect of carbon, nitrogen and oil sources was also studied. Different carbon sources used were glucose, galactose, maltose, lactose, fructose and sucrose. Nitrogen sources include peptone, yeast extract, tryptone, urea, casein and $\mathrm{NH}_{4} \mathrm{Cl}$. Different oils as inducer used were olive oil, palm oil, coconut oil, tween 80 and tributyrin. $1 \%$ of all the variables were used initially later the variable giving maximum production was changed with respect to concentration. Each time $1 \mathrm{ml}$ of set optical density was inoculated in $100 \mathrm{ml}$ of respective sterilized production medium. After appropriate incubation time, samples were drawn and lipase enzyme was extracted by centrifugation at 8000rpm. Lipase activity was determined spectrophotometrically by p-nitrophenyl laurate (p-NPL) method as described by Kumar and et al in 2014. All experiments were carried in triplicates and results noted here are mean \pm SD (Abbas, 2003; Ananthi, 2014).

\section{Extraction and purification of lipase:-}

The final production of lipase enzyme was done by growing the culture in the medium using optimized conditions and parameters. Culture supernatant containing crude lipase was obtained by centrifuging the culture medium at $8000 \mathrm{rpm}$ at $4^{\circ} \mathrm{C}$ for 30 minutes. Supernatant was used as crude enzyme. Lipase activity was determined by p-NPL method and protein content was measured by Folin lowry's method.

\section{Ammonium sulphate fractionation:-}

Lipase enzyme was partially purified by ammonium sulphate fractionation. The crude filtrate was subjected to protein precipitation by differential ammonium sulphate fractionation. It was done by addition of small increments of solid ammonium sulphate at $4^{\circ} \mathrm{C}$ with constant stirring so as to obtain fraction of $10 \%$. When all ammonium sulphate was dissolved, the mixture was refrigerated for 24 hours so as to precipitate the enzyme. The mixture was 
then centrifuged at $8000 \mathrm{rpm}$ at $4^{\circ} \mathrm{C}$ for 30 minutes. The pellet was collected and dissolved in minimum volume of $0.05 \mathrm{M}$ Phosphate buffer $\mathrm{pH} 7.0$ and supernatant was used as starting material for next precipitation. Again ammonium sulphate was added in small increment and the steps were repeated to amount fractions of $20 \%$, $30 \%, 40 \%, 50 \%, 60 \%, 70 \%, 80 \%$ and $90 \%$.

Precipitates were dialyzed against the same buffer overnight at $4^{\circ} \mathrm{C}$ by using dialysis membrane (10KDa). Lipase activity and protein content of each fraction were measured and enzyme activity, specific activity, folds purification and yield were calculated. (Benjamin, 2001; Yapasan, 2008)

\section{Results and discussion:-}

Various physico-chemical parameters were optimized to obtain maximum lipase activity are discussed below. In order to increase production of lipase enzyme, different media constituents were varied. Lipase activity was studied for different time period. Inoculum size plays an important role in increasing the production as number of cells increases the biomass. Lower inoculum could give scarce biomass while higher inoculum may produce too much biomass leading to reduced product formation with increased chances of contamination. In this study, Lipase activity was high $(116.75 \mathrm{U} / \mathrm{ml})$ after 72 hours when $1 \mathrm{ml}$ of $0.15 \mathrm{OD}$ inoculum was used (Figure no. 1). No increase in activity was observed with further increase in optical density of inoculum. Imandi and et al in 2013 have obtained maximum lipase yield of $8.43 \mathrm{U} / \mathrm{g}$ with $2 \mathrm{ml}$ of $20 \% \mathrm{w} / \mathrm{v}$ inoculum of Yarrowia lipolytica. Whereas Denise and et al in 2015 had used $1 \mathrm{ml}$ of $10^{7}$ spores suspension of Colletotrichum gloeosporioides to obtained yield of 742 U/L. (Denise et al., 2015; Imandi, 2013)

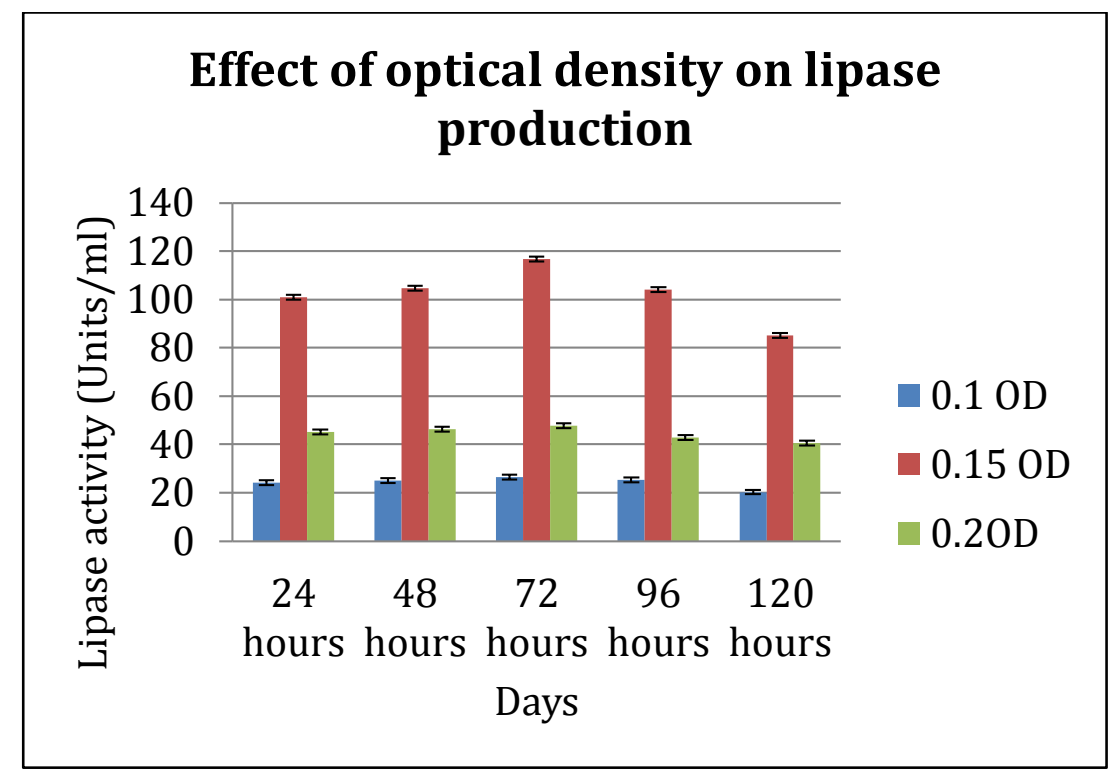

Fig 1:- Effect of optical density on lipase production

Every organism has an optimum $\mathrm{pH}$ and temperature where it exhibits highest activity. The conformation of the enzyme protein, its ionization state and the affinity of the enzyme and substrate are all influenced by the pH and temperature. Variation in $\mathrm{pH}$ and temperature affects ability of protein dissociation and net charges on it thereby resulting in change in three dimensional structures of enzyme and its function. Figure 2 demonstrates that the activity was high at $\mathrm{pH} 7.0$. Yield of $75.60 \mathrm{U} / \mathrm{ml}$ was obtained on third day with $\mathrm{pH} 7.0$. Adinarayana and et al in 2004 have obtained maximum activity at pH 7.0 with Aspergillus species. Rekha and et al in 2012 have obtained high yield at $\mathrm{pH} 6.5$ at $32^{\circ} \mathrm{C}$ when Candida rugosa was used to produce lipase. While Padmapriya and et al in 2011 have observed that Lactobacillus species gives best activity at pH 9.0 and $40{ }^{\circ} \mathrm{C}$. Similarly in this study, activity was high $(75.50 \mathrm{U} / \mathrm{ml})$ after 48 hours at $37^{\circ} \mathrm{C}$. Temperature has drastic effect on growth of living organism. At low temperature metabolism slows down, finally becoming too low to survive. Activity decreases as temperature increases as the enzyme molecules get denatured at high temperature and changes its shape (Figure no. 3). Adham and et al in 2003 reported high lipase activity at $30^{\circ} \mathrm{C}$ from Serratia marcescens. Thus pH 7.0 and temperature of $37^{\circ} \mathrm{C}$ was found to be optimum for production of lipase enzyme in this study and retained throughout the 
experiment. (Adinarayana et al., 2004; Padmapriya, Rajeswari, Noushida, Sethupalan, \& Venil, 2011; Rekha, Lakshmi, Devi, \& Kumar, 2012)

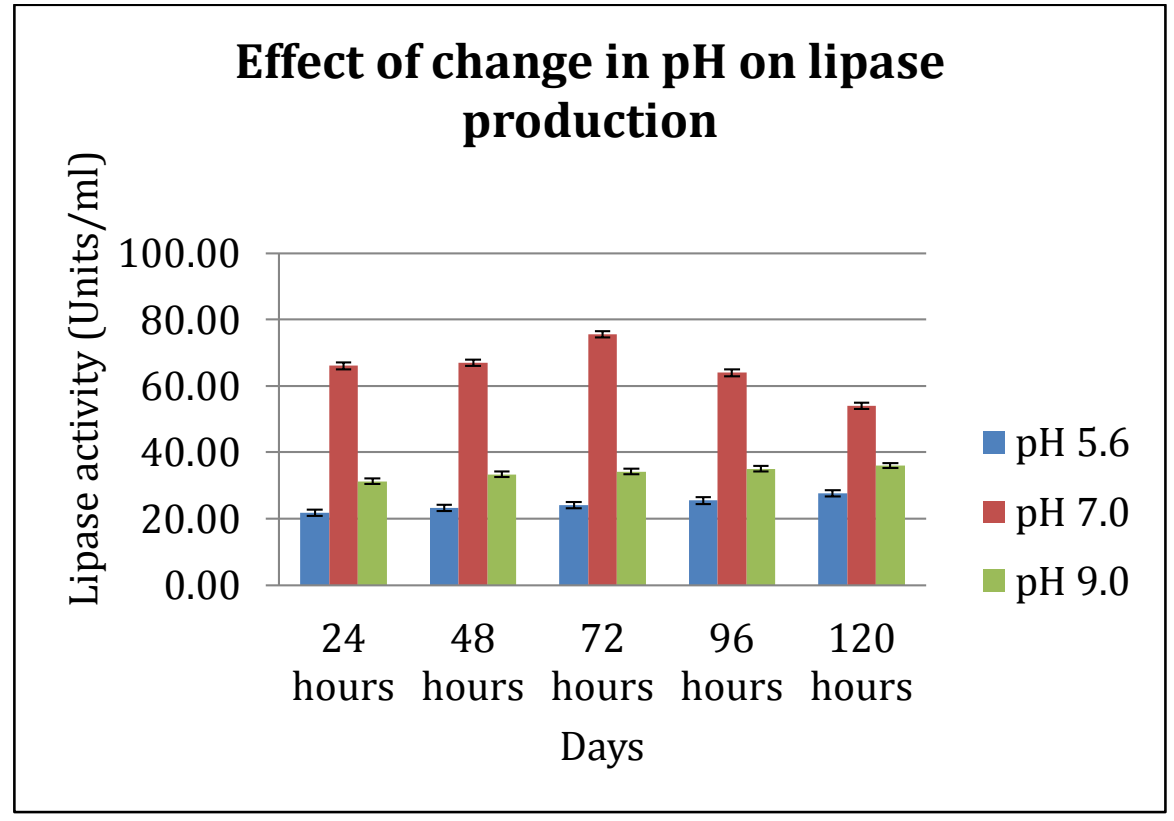

Fig 2:- Effect of change in $\mathrm{pH}$ on lipase production

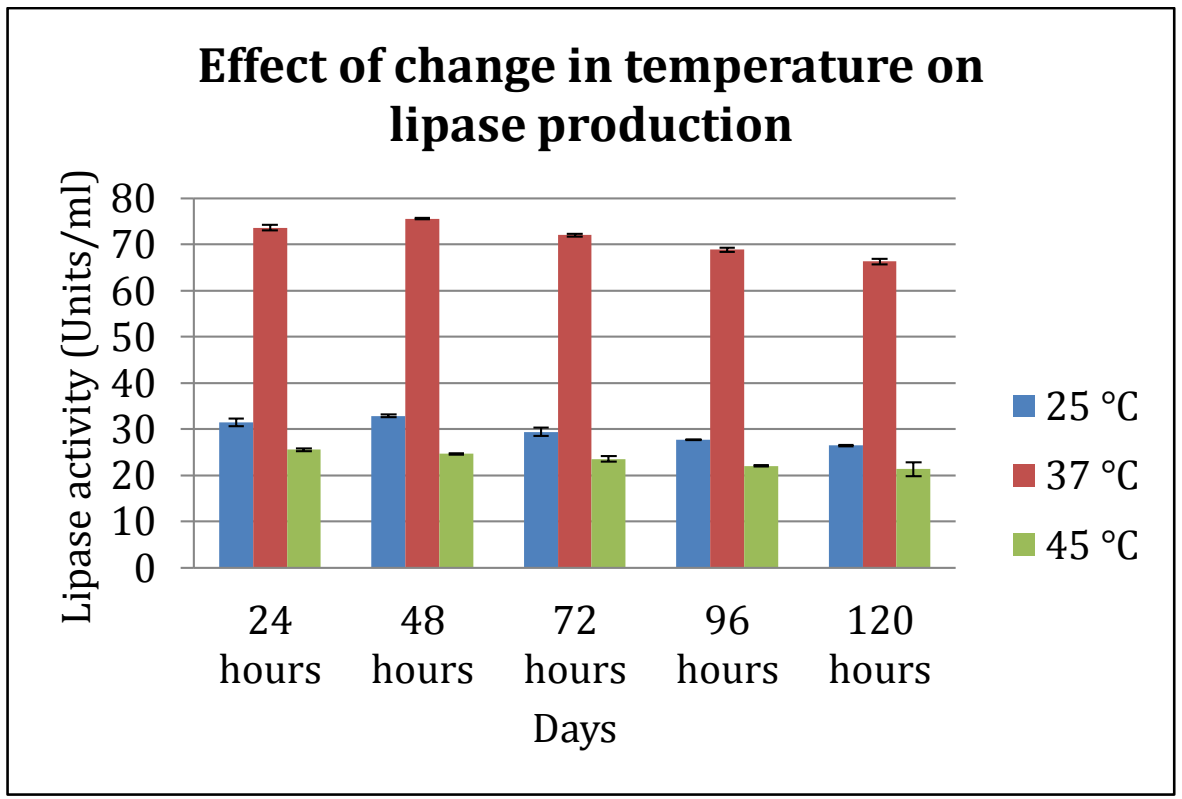

Fig 3:-Effect of change in temperature on lipase production

Effect of agitation was observed on lipase production. Oxygen tension affects activity of enzymes. With increasing speed of agitation, more oxygen is provided to growing cells. Rapid cell division takes place which increases cell biomass. However merely increase in cell biomass doesn't mean high activity. Sometime more biomass and less activity may also be obtained. In the present study, high yield of $91.62 \mathrm{U} / \mathrm{ml}$ was obtained after 72 hours of agitation at $200 \mathrm{rpm}$. Yield was low on all five days when production medium with culture was agitated at $100 \mathrm{rpm}, 150 \mathrm{rpm}$ and $250 \mathrm{rpm}$. Also the yield was less under static condition (Figure no. 4 and 5). 


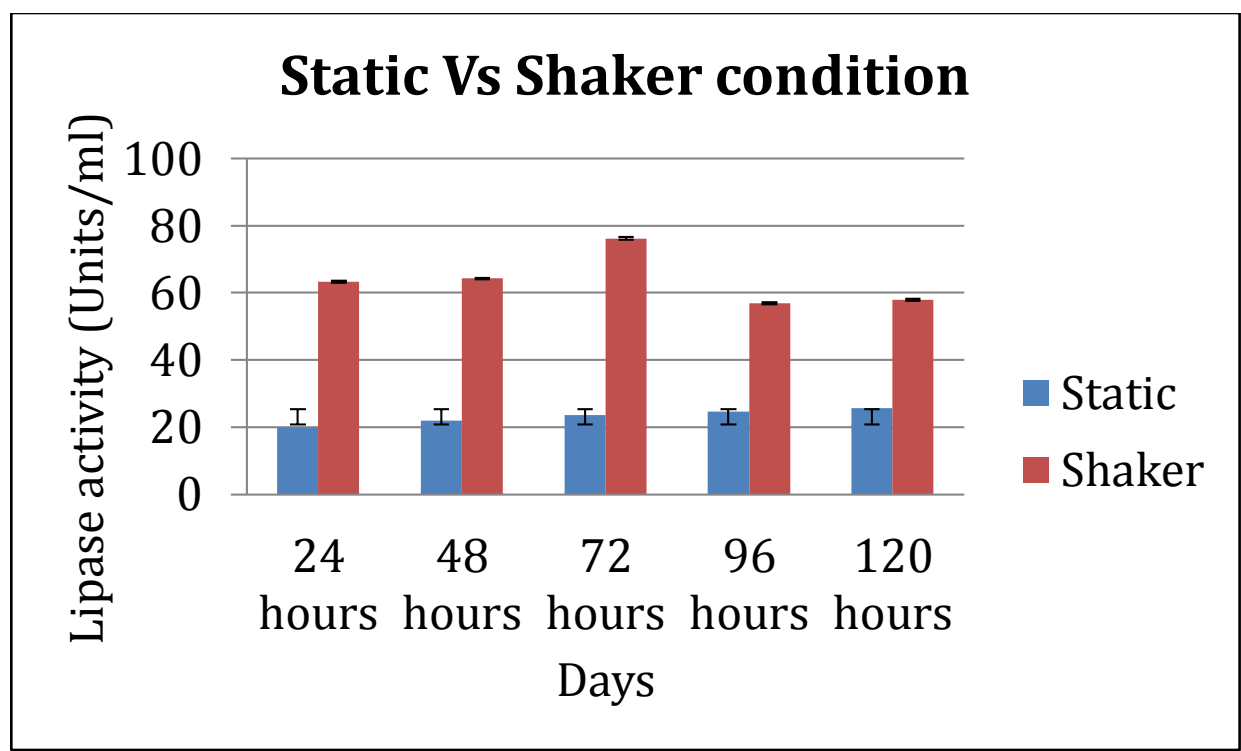

Fig 4:- Effect of Static and shaker condition on lipase production

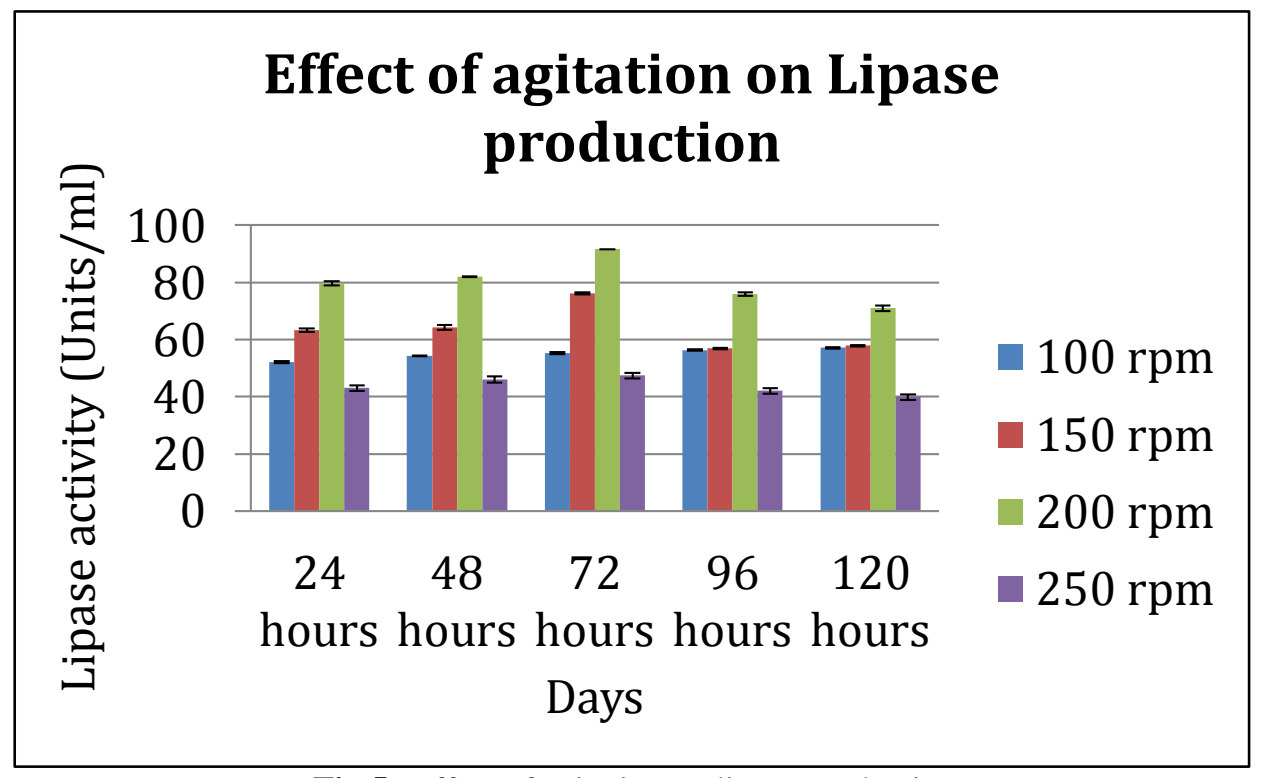

Fig 5:-Effect of agitation on lipase production

Microorganisms require energy and nutrients to build structural proteins and to drive various biochemical metabolic processes. They use carbon as their energy source. Effect of different carbon sources on lipase production by Staphylococcus gallinarum reveals that highest activity $(110.87 \mathrm{U} / \mathrm{ml})$ was obtained with glucose as compared to that with other sugars (Figure no.6). Further effect of different concentration of glucose on lipase production was studied and it was seen that $2 \%$ glucose gives maximum yield $(134.66 \mathrm{U} / \mathrm{ml})$ as compared to that with other concentrations. (Figure no. 7). 


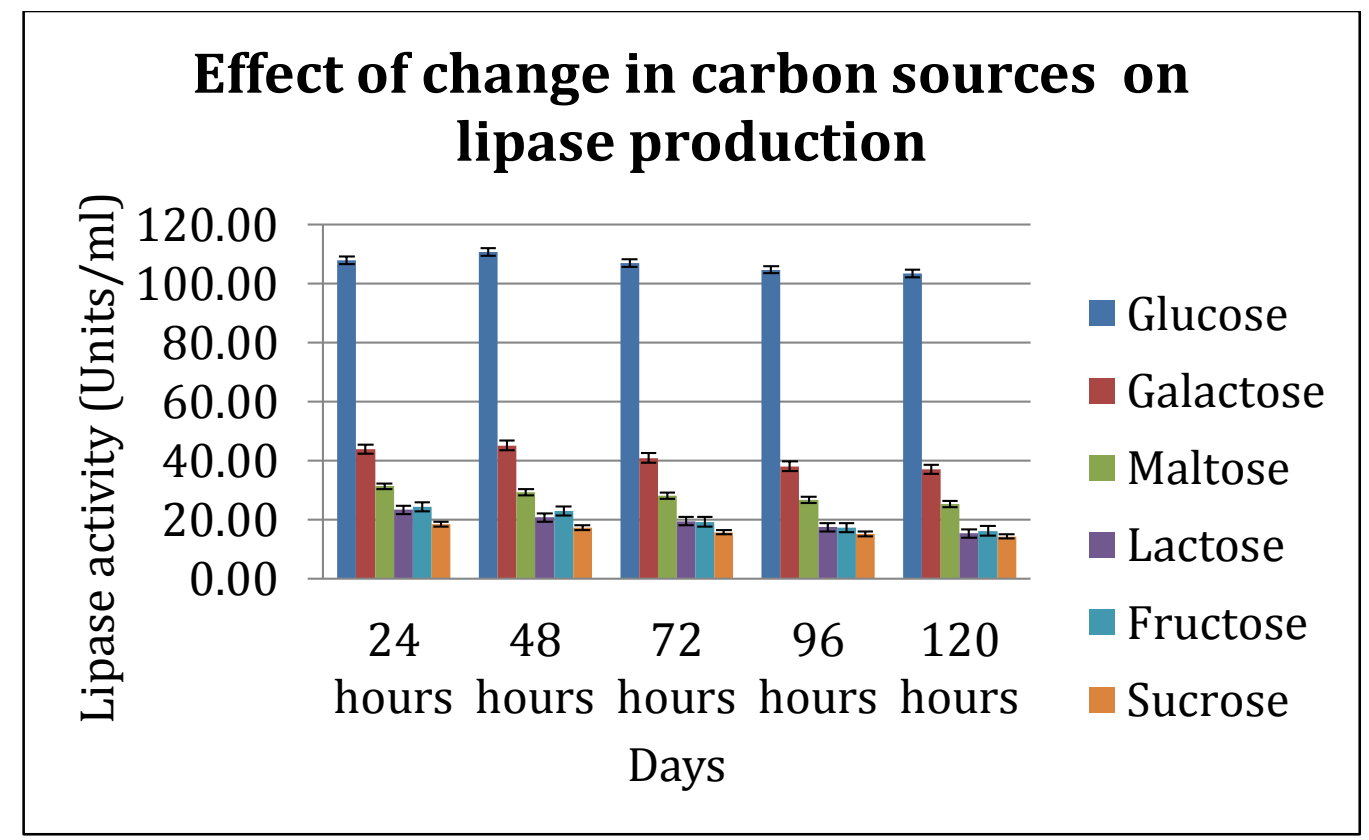

Fig 6:- Effect of change in carbon sources on lipase production

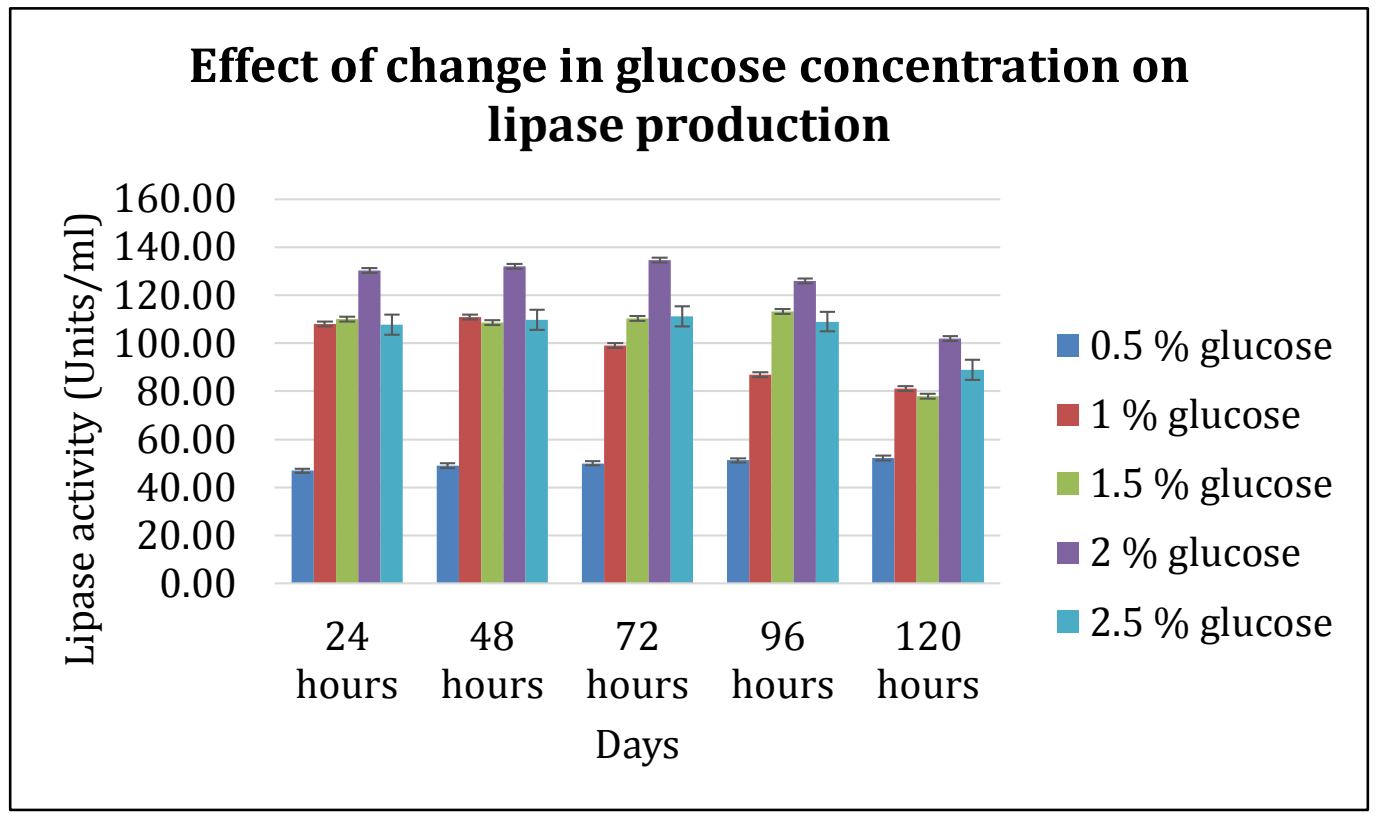

Fig 7:- Effect of change in glucose concentration on lipase production

Nitrogen is used to build amino acids, phospholipids and other cellular ingredients. Effect of different nitrogen sources was also observed. High activity $(90.10 \mathrm{U} / \mathrm{ml})$ was observed after 72 hours with peptone (Figure no.8). Studies were also carried on different concentration of peptones which reveals that $1 \%$ peptone gives high activity $(90.10 \mathrm{U} / \mathrm{ml})$ on third day of production. (Figure no. 9). 


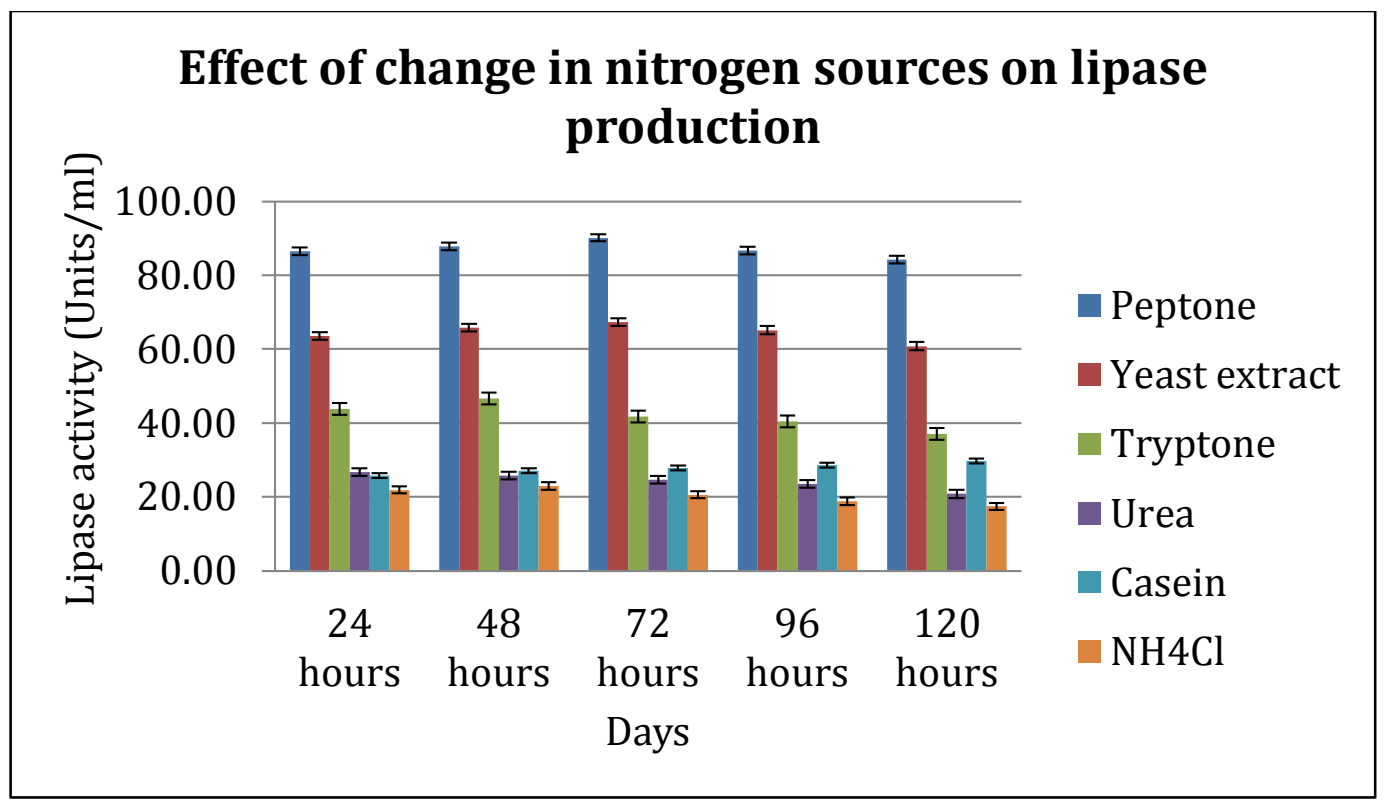

Fig 8:- Effect of change in nitrogen sources on lipase production

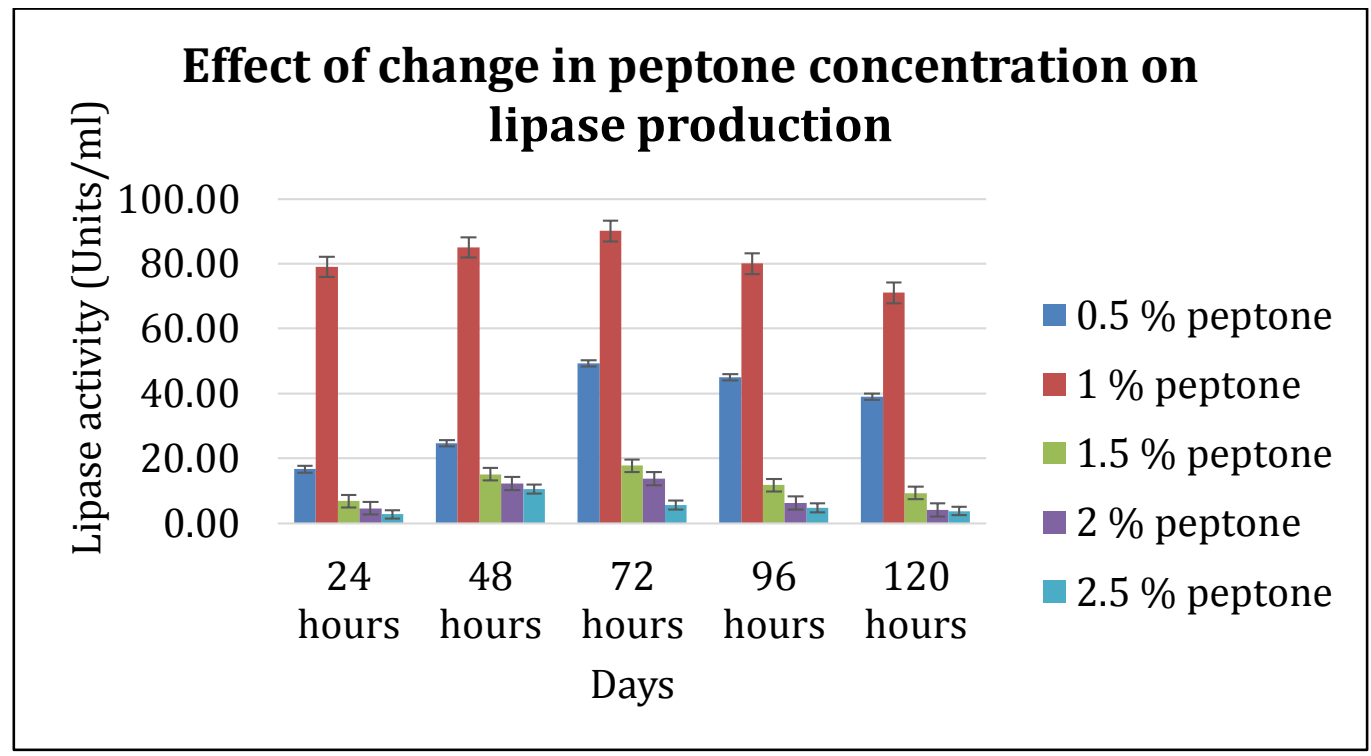

Fig 9:- Effect of change in peptone concentration on lipase production

Effect of oils and triglycerides was observed on lipase production. They can act as either inducers or inhibitors for lipase enzyme. In the present study three oils - olive oil, coconut oil, palm oil and two triglycerides - tween 80 and tributyrin were screened to check their ability to support lipase production. Results indicate that $1 \%$ olive oil gives maximum $(99.86 \mathrm{U} / \mathrm{ml}$ ) production of lipase after 72 hours (Figure no. 10). Further studies with respect to different concentration of olive oil reveal that $1 \%$ olive oil gives maximum activity of $99.86 \mathrm{U} / \mathrm{ml}$. (Figure no. 11). The fatty acid present in the greatest proportion in this oil is oleic acid (70\%). Better induction in lipase activity may be correlated with high concentration of oleic acid in the oil. 


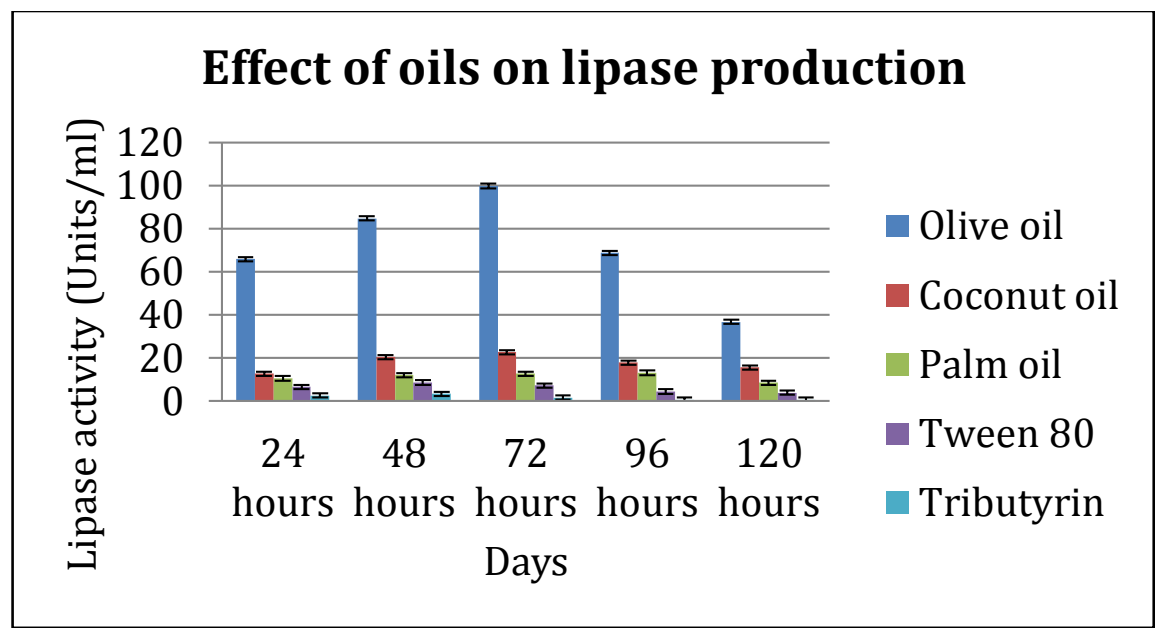

Fig 10:- Effect of oils on lipase production

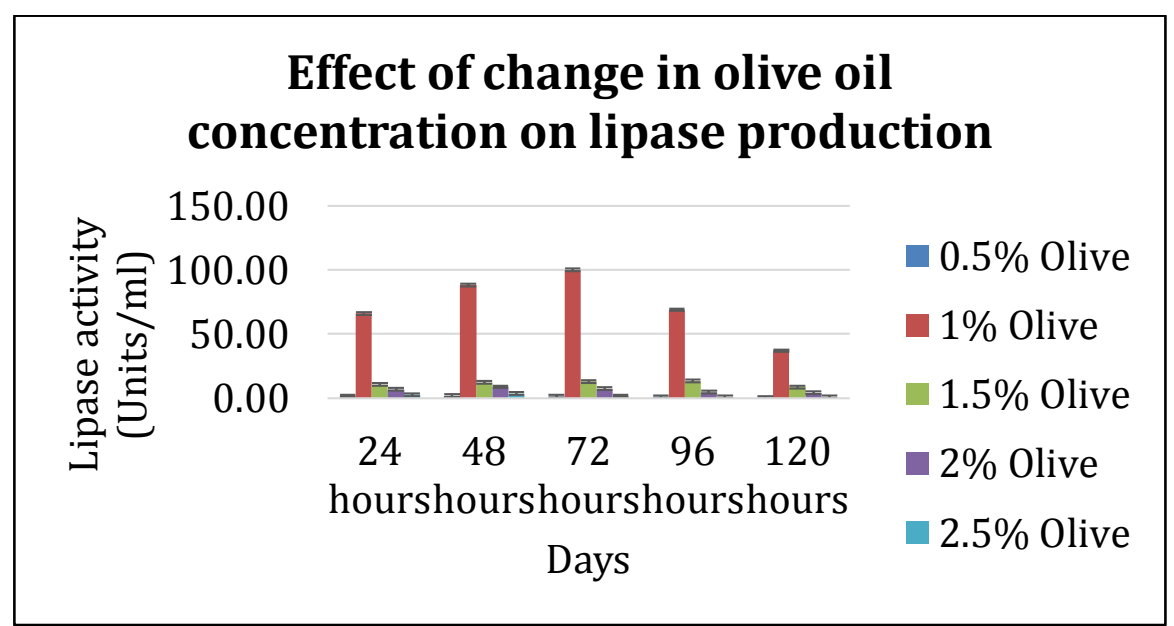

Fig 11:- Effect of change in olive oil concentration on lipase production

\section{Enzyme purification:-}

Differential ammonium sulphate precipitation was carried out with crude supernatant containing lipase. Following dialysis of the samples, its protein content and lipase activity was determined.80\% ammonium sulphate concentration gave high specific activity (8329.6 Units $/ \mathrm{mg} / \mathrm{ml}$ ) as compared to other concentrations. The enzyme was purified 29.6 fold and $19.22 \%$ yield was obtained. Benjamin and et al had obtained 43 -fold purification and $64.35 \mathrm{mg} / \mathrm{ml}$ specific activity of lipase from Staphylococcus gallinarum. They had not only used ammonium sulphate purification method but also have purified the enzyme by ultra-filtration and Sephadex gel filtration techniques (Benjamin, 2001). Whereas C. similar and et al had obtained 180.71 Units/mg/ml specific activity by ammonium sulphate precipitation (Similar, 2004). Enzyme of this high specific activity was used further to catalyze esterification and transesterification reaction.

\begin{tabular}{|c|c|c|c|c|c|}
\hline & Total protein (mg) & $\begin{array}{c}\text { Enzyme activity } \\
\text { (Units) }\end{array}$ & Specific activity (Units/mg) & Fold purification & \% Yield \\
\hline Crude & 0.277 & 7809.12 & 28204.0 & 1 & 100 \\
\hline $50 \%$ & 0.045 & 113.86 & 2545.9 & 9.0 & 1.46 \\
\hline $60 \%$ & 0.080 & 239.96 & 2996.0 & 10.6 & 3.07 \\
\hline $70 \%$ & 0.107 & 544.66 & 5116.9 & 18.1 & 6.97 \\
\hline $\mathbf{8 0 \%}$ & $\mathbf{0 . 1 8 0}$ & $\mathbf{1 4 9 9 . 9 0}$ & $\mathbf{8 3 2 9 . 6}$ & $\mathbf{2 9 . 6}$ & $\mathbf{1 9 . 2 2}$ \\
\hline $90 \%$ & 0.039 & 145.14 & 3743.7 & 13.3 & 1.86 \\
\hline
\end{tabular}

Table no 1:- Purification table for lipase from Staphylococcus gallinarum. 


\section{Conclusion:-}

The present study demonstrates effect of different parameters on maximizing lipase production from Staphylococcus gallinarum. The results obtained in this study indicate that olive oil is a good inducer for lipase induction from Staphylococcus gallinarum. Glucose and peptone serve as good carbon and nitrogen source respectively. Maximum lipase yield was obtained at optimum pH of 7.0 at $37^{\circ} \mathrm{C}$ at $200 \mathrm{rpm}$. Partially purified lipase will be purified further by gel filtration chromatography and will be used to catalyze esterification and transesterification reactions.

\section{References:-}

1. Abbas, H., \& Comeau, L. (2003). Aroma synthesis by immobilized lipase from Mucor sp. Enzyme and Microbial Technology, 32(5), 589-595.

2. Adinarayana, K., Bapi Raju, K. V. V. S. N., Iqbal Zargar, M., Bhavani Devi, R., Jhansi Lakshmi, P., \& Ellaiah, P. (2004). Optimization of process parameters for production of lipase in solid-state fermentation by newly isolated Aspergillus species. Indian Journal of Biotechnology, 3(January), 65-69.

3. Ananthi, S., Ramasubburayan, R., Palavesam, A., \& Immanuel, G. (2014). Innovare Academic Sciences Optimization and purification of lipase through solid state fermentation by bacillus cereus msu as isolated from the gut of a marine fish sardinella longiceps. International Journal of Pharmacy and Pharmaceutical Sciences, $6(5)$.

4. Benjamin, S., \& Pandey, A. (2001). Isolation and characterization of three distinct forms of lipases from candida rugosa produced in solid state fermentation. Brazilian Archives of Biology and Technology, 44, 213221.

5. Brault, G., Shareck, F., Hurtubise, Y., Lépine, F., \& Doucet, N. (2014). Short-chain flavor ester synthesis in organic media by an E. coli whole-cell biocatalyst expressing a newly characterized heterologous lipase. PloS One, 9(3), e91872.

6. Croitoru, R., Broek, L. A. M. Van Den, Frissen, A. E., Davidescu, C. M., Peter, F., \& Boeriu, C. G. (2011). Lipase Catalyzed Synthesis of Aromatic Esters of Sugar Alcohols. International Journal of Chemical, Molecular, Nuclear, Materials and Metallurgical Engineering, 5(4), 332-337.

7. Denise, S., Livia, T. A. S., Jamil, S. O., Marcelo, M. S., Inayara, C. A. L., Gecernir, C., \& Jacqueline, A. T. (2015). Colletotrichum gloeosporioides lipase: Characterization and use in hydrolysis and esterifications. African Journal of Microbiology Research, 9(19), 1322-1330.

8. Imandi, S. B., Karanam, S. K., \& Garapati, H. R. (2013). Use of Plackett-Burman design for rapid screening of nitrogen and carbon sources for the production of lipase in solid state fermentation by Yarrowia lipolytica from mustard oil cake (Brassica napus). Brazilian Journal of Microbiology, 44(3), 915-921.

9. Kocharekar, A. M., \& Dukhande, M. S. (2017). Paper Microfluidics in Microbial World. International Journal of Science and Research (IJSR), 6(3), 1909-1914.

10. Longo, M. A., \& Sanromán, M. A. (2006). Production of food aroma compounds: Microbial and enzymatic methodologies. Food Technology and Biotechnology, 44(3), 335-353.

11. Lux, L., Valeriano, L., Corbellini, A., \& Valente, P. (2007). Lipases produced by yeasts : powerful biocatalysts for industrial purposes. TECNO-LOGICA, 18-25.

12. Ortansa csutak, ileana stoica, T. V. (2015). Lipolytic activity of a new yeast strain Candida rugosa CMGB-CR6 isolated from oil-polluted soil. Romanian Biotechnological Letters, 20(3), 10547-10557.

13. Padmapriya, B., Rajeswari, T., Noushida, E., Sethupalan, D. G., \& Venil, C. K. (2011). Production of lipase enzyme from Lactobacillus spp. and its application in the degradation of meat. World Applied Sciences Journal, 12(10), 1798-1802.

14. Ramesh, S., Kumar, R., Devi, R. A., \& Balakrishnan, K. (2014). Original Research Article Isolation of a lipase producing bacteria for enzyme synthesis in shake flask cultivation. Int.J.Curr.Microbiol.App.Sci, 3(3), 712-719.

15. Rekha, K. S. S., Lakshmi, M. V. V. C., Devi, V. S., \& Kumar, M. (2012). Production and Optimization of Lipase From Candida Rugosa Using Groundnut Oilcake Under Solid State, 571-577.

16. Similar, C. (2004). Chapter 3 results and discussion Part 1 . Synthesis of Sugar Esters from Palm Oil and Palm Fatty Acid Distillates using Commercial Lipases, 61-148.

17. Veerapagu, M., Sankara Narayanan, a., Ponmurugan, K., \& Jeya, K. R. (2013). Screening selection identification production and optimization of Bacterial Lipase from oil spilled soil. Asian Journal of Pharmaceutical and Clinical Research, 6(SUPPL.3), 62-67.

18. Yapasan, E., \& Yalcin, A. P. D. R. T. (2008). Partial purification and characterization of lipase enzyme from a Pseudomonas strain. School of Engineering and Science, Master of(December), 49. 